\title{
Expression and localisation of vascular endothelial growth factor and basic fibroblast growth factor during the final growth of bovine ovarian follicles
}

\author{
B Berisha, D Schams, M Kosmann, W Amselgruber ${ }^{1}$ \\ and $\mathbf{R}$ Einspanier \\ Institute of Physiology, Technical University of Munich, Weihenstephaner Berg 3, D-85350 Freising-Weihenstephan, Germany \\ ${ }^{1}$ Department of Anatomy and Physiology, University of Hohenheim, D-70593 Stuttgart, Germany \\ (Requests for offprints should be addressed to D Schams; E-mail: physio@weihenstephan.de)
}

\begin{abstract}
Locally produced growth factors may have important modulatory roles in final ovarian follicular growth. The aim of this study was to investigate the possible participation of vascular endothelial growth factor (VEGF) and basic fibroblast growth factor (FGF2) in bovine follicles during final growth. Ovaries were collected from a slaughterhouse within 10-20 min after exsanguination. A classification of follicles into five groups $(<0.5 ;>0.5-5$; $>5-20 ;>20-180 ;>180 \mathrm{ng} / \mathrm{ml})$ was performed according to the follicular fluid (FF) oestradiol-17 $\beta$ content. For a better characterisation of classes the mRNA expressions of FSH receptor, LH receptor and aromatase cytochrome P450 in theca interna (TI) and granulosa cells (GC) were determined. Analysis of VEGF transcript by RT-PCR showed that GC and theca cells express predominantly the smallest isoforms $\left(\mathrm{VEGF}_{121}\right.$ and $\left.\mathrm{VEGF}_{165}\right)$. VEGF mRNA expression in both tissues (TI and GC) and VEGF protein concentration in total follicle tissue increased significantly (and correlated) with developmental stages of follicle growth. The expression of mRNA for VEGF receptor (VEGFR)-1 and VEGFR-2 was very weak in GC,
\end{abstract}

without any regulatory change during final follicle growth. In contrast, TI showed strong expression of mRNA for both receptors in all follicle classes examined. VEGF protein concentrations in FF increased significantly and continuously to maximum levels in preovulatory follicles. As shown by immunohistochemistry, VEGF protein was clearly localised in TI and GC of preovulatory follicles. FGF2 and FGF receptor (FGFR) mRNA expression in TI increased significantly during final growth of follicles. In contrast, the FGF2 and FGFR mRNA expression in GC was very weak and without any regulatory change during follicle growth. Histological observation revealed that FGF2 protein was localised in theca tissue (cytoplasm of endothelial cells and pericytes) but not in GC.

Our results suggest that VEGF and FGF families are involved in the proliferation of capillaries that accompanies the selection of the preovulatory follicle resulting in an increased supply of nutrients and precursors, and therefore supporting the growth of the dominant follicle.

Journal of Endocrinology (2000) 167, 371-382

\section{Introduction}

In cattle, ovarian follicular development is characterised by two or three consecutive follicular waves per oestrous cycle (Savio et al. 1988, Sirois \& Fortune 1988). Each wave involves the recruitment of a cohort of follicles and the selection of a dominant follicle, which continues to grow and mature to the preovulatory stage while others in the wave undergo atresia. A complex regulatory system (still not well understood) must exist to determine which follicles are selected. Although it is well established that ovarian function is regulated primarily by the pituitary gonadotrophins follicle-stimulating hormone (FSH) and luteinising hormone (LH) and their receptors (FSHR, LHR), it is also evident that locally produced factors such as steroid hormones, peptides and growth factors have modulatory roles in follicular development (Fortune 1994).

That angiogenesis, the formation of new capillaries to a dense network, may play an important role in the selection process was suggested by previous studies that demonstrated that the selected follicle possesses a more elaborate microvasculature than other follicles (Zeleznik et al. 1981). In view of the importance of angiogenesis in ovarian function, the elucidation of the factors that are responsible for selective vascularisation of the follicle is central for the understanding and control of both normal and abnormal ovarian function. A number of polypeptide growth factors have been demonstrated to be angiogenic in vivo (Klagsbrun \& D'Amore 1991). Angiogenic factors 
produced by the corpora lutea of cows, pigs and sheep are primarily heparin-binding and can be immunoneutralised with antibodies against fibroblast growth factors (FGFs) and vascular endothelial growth factors (VEGFs) (Gospodarowicz \& Thakral 1978, Grazul-Bilska et al. 1993).

VEGF is known as a potent mitogen for endothelial cells (Ferrara \& Davis-Smyth 1997) and as a stimulator of vascular permeability (Connolly 1991, Senger et al. 1993). These biological activities are important in the cascade of events leading to angiogenesis. VEGF is the most important factor in the regulation of normal and abnormal angiogenesis (Ferrara \& Davis-Smyth 1997). Molecular cloning of the cDNAs revealed that human VEGF may exist as one of four different molecular species, having 121, 165, 189 and 206 amino acids. Bovine VEGF is expected to be one amino acid shorter (Tischer et al. 1989). VEGF isoforms are encoded by the same gene, through alternative splicing of mRNA. The resulting four polypeptides have strikingly different secretion patterns, which suggests multiple physiological roles for VEGF isoforms. The two smaller members of this family are secreted by cells and may act paracrinely, while the third and fourth are mostly cell associated and may act autocrinely, despite the fact that all members have an identical signal sequence (Ferrara et al. 1992). The biological activities of VEGF are mediated by two high affinity receptor tyrosine kinases (Ferrara \& Davis-Smyth 1997). The fms-like tyrosine kinase or VEGF receptor (VEGFR)-1 and the fetal liver kinase-1 or VEGFR-2 possess seven immunoglobulin-like domains in the extracellular domain, a single transmembrane region and a consensus tyrosine kinase sequence that is interrupted by a kinase insert domain.

FGFs are necessary for many biological processes such as cell growth, differentiation, angiogenesis, tissue repair and transformation. The FGFs have a wide range of tissue and cell distribution (Gospodarowicz et al. 1987). The two most famous members of this group, FGF1 (acidic) and FGF2 (basic), are closely related. FGF2 has been identified as a potential regulator of ovarian function (Gospodarowicz et al. 1986, Schams et al. 1994). The FGF receptor (FGFR) family includes four identified genes and numerous subtypes of alternatively spliced isoforms, particularly within the wellcharacterised FGFR-1 and FGFR-2 types. Differential responses follow from this diversity (Stauber et al. 2000). In the rat ovary FGFR-1 and FGFR-2 are the most important receptors (Asakai et al. 1994).

The expression and localisation of VEGF and FGF2 during final follicular growth is not well documented in large animals. The aim of the present study was to evaluate the expression pattern of mRNA for VEGF, FGF2 and their receptors, tissue and follicular fluid (FF) concentrations of VEGF and localisation of VEGF and FGF2 in bovine antral follicles during final growth to the preovulatory stage.

\section{Materials and Methods}

\section{Collection of follicles and preparation}

Entire reproductive tracts from German Fleckvieh cows were collected at a local slaughterhouse within 10-20 min after slaughter and were transported on ice to the laboratory. The stage of the oestrous cycle was defined by macroscopic observation of the ovaries (colour, consistency, corpus luteum stage, number and size of follicles) and the uterus (colour, consistency and mucus). Only follicles which appeared healthy (i.e. well vascularised and having transparent follicular wall and fluid) and whose diameter was $>5 \mathrm{~mm}$ were used. Large follicles $(>14 \mathrm{~mm})$ were collected only after corpus luteum regression, with signs of mucus production in the uterus and cervix and were assumed to be preovulatory. For immunohistochemical investigations after aspiration of the FF, the follicles were fixed via immersion with methanol/glacial acid $2 / 1 \mathrm{v} / \mathrm{v}$ for FGF2 and Bouin's solution for VEGF. For the RNA extraction the follicles were dissected from the ovary. The surrounding tissue (theca externa) was removed with forceps under a stereo microscope. After aspiration of FF, the follicles were bisected and their inside wall was gently scraped and flushed with Ringer's solution (Fresenius, Wendel, Germany) to remove the granulosa cells (GC). The GC in the FF as well as in the flushing solution were centrifuged at $2000 \mathrm{~g}$ for $10 \mathrm{~min}$ at $4{ }^{\circ} \mathrm{C}$. The theca interna tissue (TI) and GC pellet were snap frozen in liquid nitrogen and stored at $-80{ }^{\circ} \mathrm{C}$ until RNA isolation. For follicle VEGF tissue extraction, after aspiration of $\mathrm{FF}$, follicle tissue was stored at $-80{ }^{\circ} \mathrm{C}$. The FF was stored at $-20{ }^{\circ} \mathrm{C}$ until determination of progesterone, oestradiol-17 $\beta$ and VEGF.

\section{Follicle classification}

Since healthy follicles have relatively constant progesterone levels in FF, only follicles with progesterone below $100 \mathrm{ng} / \mathrm{ml} \mathrm{FF}$ were used for the evaluation, to exclude atretic follicles. For further characterisation of the follicle classes, mRNA expression was determined for the FSHR and aromatase cytochrome P450 (ARO) in GC and LHR in TI and GC.

The follicles were classified according to the oestradiol-17 $\beta$ content in FF as follows; (i) $<0.5$; (ii) $>0.5-5$; $\quad$ (iii) $>5-20$; (iv) $>20-180$; and (v) $>180 \mathrm{ng} / \mathrm{ml} \mathrm{FF}$. The corresponding size of follicles were in the range of (i) $5-7 \mathrm{~mm}$; (ii) $8-10 \mathrm{~mm}$; (iii) $10-13 \mathrm{~mm}$; (iv) $12-14 \mathrm{~mm}$; and (v) $>14 \mathrm{~mm}$.

\section{Hormone determinations}

Concentrations of progesterone and oestradiol-17 $\beta$ were determined directly in the FF with an enzyme immunoassay using the second antibody technique (Prakash et al. 
1987, Meyer et al. 1990). We used as enzyme solution progesterone- $6 \beta$-hydroxy-hemisuccinate-horseradish peroxidase (HRP) or oestradiol-17 $\beta$-6-carboxy-methyloxim-HRP. Each polyclonal antibody was raised in a rabbit against progesterone- $7 \alpha$-carboxyethylthioetherBSA or for oestradiol against oestradiol-17 $\beta-6-$ carboxymethyloxim-BSA. The effective dose for $50 \%$ inhibition $\left(\mathrm{ED}_{50}\right)$ of the assay was $6 \mathrm{ng} / \mathrm{ml}$ for progesterone and $3.5 \mathrm{pg} / \mathrm{ml}$ for oestradiol-17 $\beta$. The FF was diluted accordingly. The intraassay variations were $4-5 \%$ (progesterone) and 6-7\% (oestradiol-17 $\beta$ ) and the interassay variations $8-9 \%$ (progesterone) and 9-10\% (oestradiol-17 $\beta$ ).

Concentrations of VEGF in FF and homogenate supernatant of follicles were measured in $200 \mu \mathrm{l}$ by RIA using a rabbit antiserum raised against recombinant bovine VEGF $_{164}$ (prepared in our laboratory). The antibody cross-reacts with all four human isoforms of VEGF $\left(V_{E G F}{ }_{121}, 165,189,206\right)$. The cross-reactivities to the other growth factors platelet-derived growth factors (PDGF)AA, PDGF-BB, PDGF-AB, FGF1, FGF2 and transforming growth factor- $\alpha$ were below $0 \cdot 1 \%$. The recombinant $\mathrm{VEGF}_{164}$ was used for iodination by the iodogen method as described recently (Richards \& Almond 1994). Labelled VEGF was separated from free iodine with a prepacked disposable NAP-1O column containing Sephadex G-25 medium (Amersham-Pharmacia, Freiburg, Germany). Elution of the column was performed with $0.05 \mathrm{M}$ phosphate buffer $\mathrm{pH} 7 \cdot 5$ containing $0 \cdot 2 \%$ sodium acid in $0.5 \mathrm{ml}$ fractions into tubes containing $200 \mu \mathrm{l} 0.05 \mathrm{M}$ phosphate buffer, $1 \%$ BSA and $0 \cdot 2 \%$ sodium acid. To fractions with labelled VEGF, glycerine was added up to $50 \%$ and they were stored at $-20{ }^{\circ} \mathrm{C}$ until use in RIA. The tracer was stable for 3-4 months. The incubation buffer for RIA was $3 \mathrm{M} \mathrm{NaCl}$ containing 1\% BSA, $0 \cdot 1 \%$ Triton X-100, $\mathrm{pH} 7 \cdot 5$. The antiserum was used at a final dilution of 1/400 000. Separation of bound and free VEGF was completed using the double antibody technique and 6\% polyethylene glycol 6000 (Serva, Heidelberg, Germany). The intraassay and interassay variations were below 6 and 14\% respectively. The $\mathrm{ED}_{50}$ of the assay was $0.6 \mathrm{ng} / \mathrm{ml}$. Dilutions of samples containing endogenous VEGF or added VEGF from blood plasma, cell culture medium, tissue extracts or FF ran parallel to the standard curve. The average recovery of exogenous VEGF was 93-96\%.

\section{Tissue extraction of VEGF}

Follicle tissue $(1 \mathrm{~g})$ from pools of small follicles $(n=5$ pools, 4-6 follicles/pool; <9 mm; oestradiol- $17 \beta<12 \mathrm{ng} / \mathrm{ml} \mathrm{FF}$ ) and large follicles ( $n=5$ pools, $2-3$ follicles/pool; $>12 \mathrm{~mm}$; oestradiol- $17 \beta>30 \mathrm{ng} / \mathrm{ml} \mathrm{FF}$ ) were transferred into 10 volumes of PBS containing 0.1\% 1,4-dithiothreitol (Merck Co., Darmstadt, Germany) and homogenised in an ice bath by Ultra Turrax (Janke and Kunkel, Staufen,
Germany). Five bursts of $15 \mathrm{~s}$ at maximum speed with 45 s intervals of cooling between each burst were applied. The homogenate was subsequently centrifuged at $2000 \boldsymbol{g}$ for $15 \mathrm{~min}$ at $4{ }^{\circ} \mathrm{C}$. The supernatant was separated into $1 \mathrm{ml}$ aliquots and kept frozen until analysis.

\section{Immunohistochemistry}

After $12 \mathrm{~h}$ fixation the follicles were dehydrated in a graded series of ethanol, cleared in xylene and embedded in paraffin wax using conventional procedures. Serial sections of $5 \mu \mathrm{m}$ thickness were cut on a microtome and processed for immunohistochemistry.

Immunohistochemical demonstration of VEGF and FGF2 was performed according to the avidin-biotin peroxidase complex (ABC) method (Hsu et al. 1981). To expose antigenic sites for VEGF, dewaxed sections were heated four times to $95{ }^{\circ} \mathrm{C}$ in a $600 \mathrm{~W}$ microwave oven maintained for $5 \mathrm{~min}$ and allowed to cool for $20 \mathrm{~min}$. The sections were then treated with hydrogen peroxide (1\%) in methanol for $30 \mathrm{~min}$ to block endogenous peroxidase; normal goat serum diluted 1:10 in PBS for $20 \mathrm{~min}$ to reduce non-specific background staining; polyclonal antiVEGF antibody 1:300 in PBS (the same antibody as used for RIA), overnight at $4{ }^{\circ} \mathrm{C}$; biotinylated secondary antibody (goat anti-rabbit $\operatorname{IgG} 1: 400$ ) $30 \mathrm{~min}$ at room temperature; and StreptAB-HRP complex (DAKO, Hamburg, Germany) $30 \mathrm{~min}$ at room temperature, followed by histochemical visualisation of peroxidase using 3',3'diaminobenzidine hydrochloride chromogen (Biotrend, Cologne, Germany) in 0.0006\% hydrogen peroxide-0.05 M Tris buffer, $\mathrm{pH} 7 \cdot 6$ for $5 \mathrm{~min}$ in a dark room.

For FGF2, potential endogenous peroxidase activity was suppressed by incubation with methanolic hydrogen peroxide followed by an overnight incubation at $4{ }^{\circ} \mathrm{C}$ with 1:1200 dilutions of rabbit anti-FGF2 (polyclonal antibody \#14, prepared in our laboratory and raised again recombinant bovine FGF2). After washing in PBS the sections were incubated for $30 \mathrm{~min}$ with biotinylated goat antirabbit IgG. The sections were then reacted with $\mathrm{ABC}$ reagent from a commercial kit (Vector Laboratories, Burlingame, CA, USA). The bound complex was made visible by reaction with $0.05 \% \quad 3,3^{\prime}$ diaminobenzidine hydrochloride and $0 \cdot 0006 \%$ hydrogen peroxide in $0 \cdot 1 \mathrm{M}$ PBS.

The specificity of the immunocytochemical reactions was assessed by: (i) replacement of the primary antibody with buffer; (ii) its substitution with non-immune goat IgG (1:10 diluted); (iii) incubation with diaminobenzidine reagent alone to exclude the possibility of non-suppressed endogenous peroxidase activity; and (iv) an absorption test involving the respective antigen $(15 \mu \mathrm{g} / \mathrm{ml})$. Lack of detected staining of tissue elements in the controls demonstrated the specificity of the reactions. 
Table 1 Gene transcript, number of cycles used, primer sequences and resulting fragment size

\begin{tabular}{|c|c|c|c|c|}
\hline & $\begin{array}{l}\text { Cycle } \\
\text { number }\end{array}$ & Sequence of nucleotide* & $\begin{array}{l}\text { Fragment } \\
\text { size (bp) }\end{array}$ & EMBL/reference** \\
\hline \multicolumn{5}{|l|}{ Target } \\
\hline FSHR & 30 & For 5'-AAT TTG TCA CAC TCG TGG AGG-3' & 222 & L 22319 \\
\hline \multirow[t]{2}{*}{ LHR } & 30 & For $5^{\prime}$-AGA AGA TGC ACA ACG C-3' & 326 & U 41413 \\
\hline & & Rev 5'-TTC AGG AGC ACA CTG GAG TG-3' & & \\
\hline $\mathrm{ARO}$ & 20 & For 5'-AAG CCT TAG AGG ATG ATG TC-3' & 326 & Z 32741 \\
\hline VEGF & & Rev 5'-TCA CCG CCT CGG CTT GTC ACA-3' & & \\
\hline \multirow[t]{2}{*}{ VEGFR-1 } & 30 & For 5'-CAC CAA GAG CGA CGT GTG-3' & 351 & Gabler et al. (1999) \\
\hline & & Rev 5'-AAG AAG TCC TCG GAG AAG GC-3' & & \\
\hline \multirow[t]{2}{*}{ VEGFR-2 } & 30 & For 5'-AGA CTG GTT CTG GCC CAA C-3' & 379 & Gabler et al. (1999) \\
\hline & & Rev 5'-GAA GCC TTT CTG GCT GTC-3' & & \\
\hline FGF2 & 30 & For 5'-GAA CGG GGG CTT CTT CCT-3' & 288 & Gabler et al. (1997) \\
\hline Ubiquitin & & Rev 5'-CTT CTG GAT GTT GTA GTC-3' & & \\
\hline
\end{tabular}

*For, forwards; Rev, reverse; R, A or G; M, A or C; Y, C or T; S, G or C.

${ }^{* *} \mathrm{EMBL}$ accession number or reference of published sequence.

\section{$R T-P C R$}

Total RNA from TI tissue was isolated by the single step method of Chomczynski \& Sacchi (1987) using TRIzol reagent (Gibco BRL, Gaithersburg, MD, USA). Total RNA from GC was isolated using the NucleoSpin RNA kit (Macherey-Nagel, Dueren, Germany). RNA was dissolved in water and spectroscopically quantified at $260 \mathrm{~nm}$. Aliquots were subjected to $1 \%$ denaturing agarose gel electrophoresis and ethidium bromide staining to verify the quantity and quality of RNA.

Two micrograms of total RNA were used to generate single-strand cDNA in a $60 \mu$ reaction mixture by use of hexanucleotides as primers according to the protocol for the M-MLV Reverse Transcriptase Kit (Promega, Madison, WI, USA). The optimal amount of total RNA for reverse transcription was evaluated by testing different RNA concentrations. The primers were designed using the EMBL database or were used as described elsewhere (Table 1) and were commercially synthesised (AmershamPharmacia). Except those for FGFR, all primer pairs were designed according to known bovine sequences. For FGFR primers from consensus cDNA portions of highly conserved regions within the cytoplasmic tyrosine kinase domains of all four FGFR types were used (Xin et al. 1994). The VEGF primer allows detection of all four isoforms (186, 318, 390 and $441 \mathrm{bp})$ representing $\mathrm{VEGF}_{121}, \mathrm{VEGF}_{165}, \mathrm{VEGF}_{189}$, and $\mathrm{VEGF}_{206}$ (Garrido et al. 1993). The number of amplification cycles, primer sequence and resulting fragment size for all examined factors are shown in Table 1. The conditions for enzymatic amplification (RT-PCR) were established on a gradient cycler (Eppendorf, Hamburg, Germany). The PCR for all examined factors contained $10 \mathrm{mM}$ Tris- $\mathrm{HCl}(\mathrm{pH} \mathrm{8.8)}$, $50 \mathrm{mM} \mathrm{KCl}, 1.5 \mathrm{mM} \mathrm{MgCl}_{2}$ (FGF2, 1.0 mM $\mathrm{MgCl}_{2}$ ), $0 \cdot 1 \%$ Triton $\mathrm{X}-100,0.6 \mu \mathrm{M}$ each primer and 0.5 units of thermostable polymerase PrimeZyme (Biometra, Göttingen, Germany) to $3 \mu \mathrm{l}$ cDNA (final volume $25 \mu \mathrm{l}$ ). Ubiquitin PCR was performed under the same conditions, but a higher concentration of primer $(1 \cdot 0 \mu \mathrm{M})$ was used. All amplifications were done as follows: an initial denaturation step at $94^{\circ} \mathrm{C}$ for $2 \mathrm{~min}$, each cycle at $94{ }^{\circ} \mathrm{C}$ for $1 \mathrm{~min}, 60^{\circ} \mathrm{C}$ for $1 \mathrm{~min}$ (VEGF, $55^{\circ} \mathrm{C}$ and VEGFR-2, $64^{\circ} \mathrm{C}$ ) and afterwards one additional elongation step at $72{ }^{\circ} \mathrm{C}$ for $2 \mathrm{~min}$. Samples for the housekeeping gene ubiquitin were amplified for 22 cycles: a single denaturation step at $94{ }^{\circ} \mathrm{C}$ for $2 \mathrm{~min}$, each cycle at $94{ }^{\circ} \mathrm{C}$ for $45 \mathrm{~s}$, $55{ }^{\circ} \mathrm{C}$ for $45 \mathrm{~s}, 72{ }^{\circ} \mathrm{C}$ for $45 \mathrm{~s}$ and afterwards one additional elongation step at $72{ }^{\circ} \mathrm{C}$ for $2 \mathrm{~min}$.

To determine the optimal quantity of reverse transcript needed for PCR and to verify that the cDNA product was dependent on the input of transcript, varying quantities of transcript were used in the PCR reaction. The RT product in $3 \mu \mathrm{l}$ was in the linear range for these amounts and produced a visible band. To exclude any contaminating genomic DNA, all experiments included controls lacking the RT enzyme. As a negative control water was used instead of RNA for the RT-PCR to exclude any contamination from buffers and tubes.

Aliquots of the PCR reaction products $(5 \mu \mathrm{l})$ were fractionated by electrophoresis through a $1.5 \%$ agarose gel containing ethidium bromide in a constant $60 \mathrm{~V}$ field. To determine the length of the products, a Mass Ladder and $100 \mathrm{bp}$ marker (Gibco BRL) were used. The ethidium 

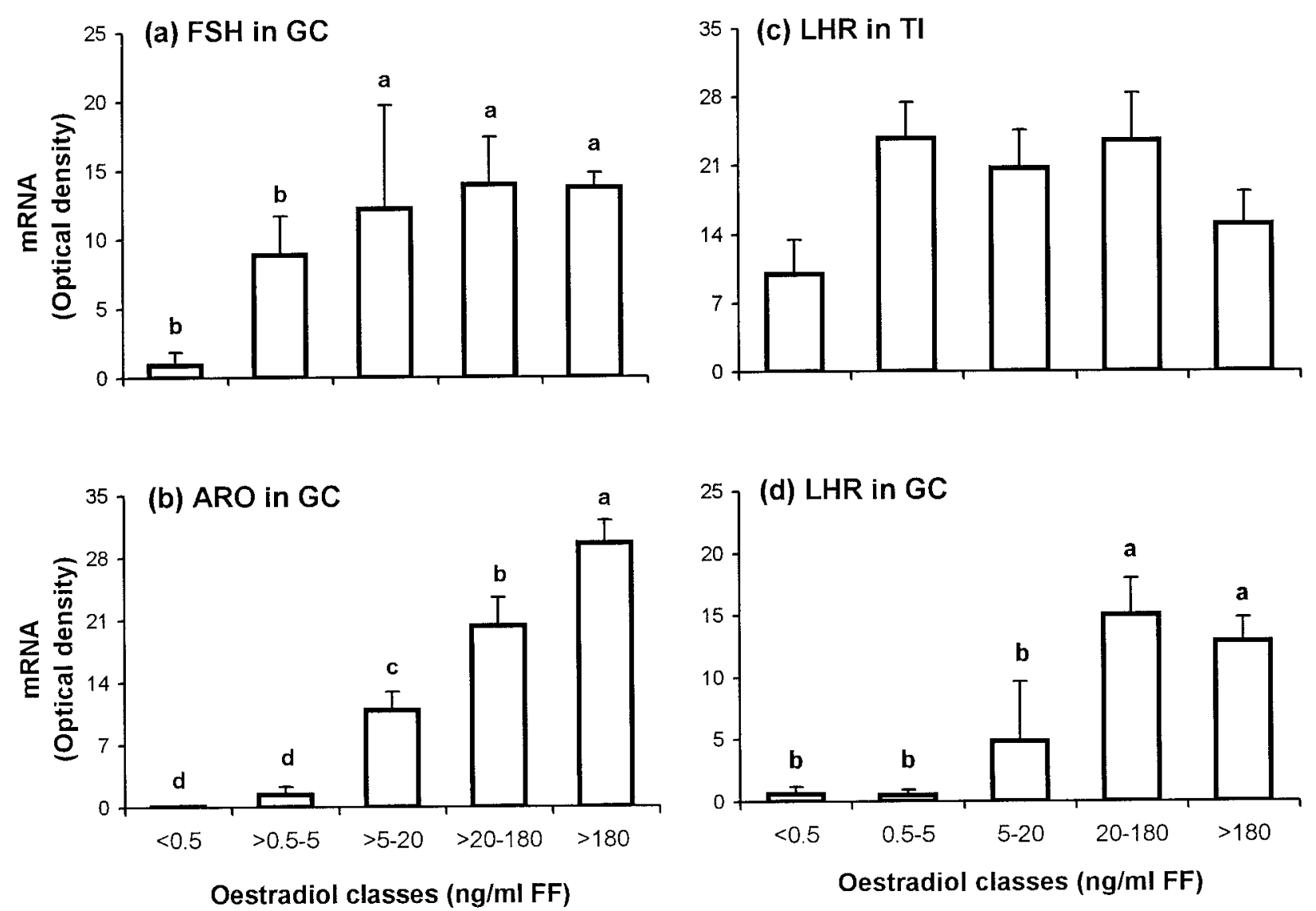

Figure 1 Densitometrically analysed RT-PCR results (arbitrary units) in different bovine follicle classes. (a) FSHR in GC (30 cycles); (b) ARO in GC (20 cycles); (c) LHR in TI (30 cycles); (d) LHR in GC (30 cycles). Data are expressed as a means \pm S.E.M. $(n=4-9$ follicles/class). Different superscripts denote statistically different values $(P<0 \cdot 05)$.

bromide-stained gels were evaluated by a video documentation system (Amersham-Pharmacia). For comparison of treatment effects all gels being compared were run and stained at the same time to ensure that apparent differences detected were indeed due to treatments and not the result of between-run variability. Band intensities (relative) were analysed by computerised densitometry (arbitrary units) using the Image Master program (Amersham-Pharmacia). However, RT-PCR and the evaluation technique used are relative and not a strictly quantitative method. Confirmation of the PCR product identity was obtained by subcloning the cDNA into a transcription vector (PCRScript; Stratagene, La Jolla, CA), followed by commercial DNA sequencing (TopLab, Munich, Germany).

\section{Statistical analyses}

The statistical significance of differences in mRNA expression and protein concentration of examined factors was assessed by ANOVA, followed by Fisher's LSD as a multiple comparison test. All experimental data are shown as means \pm S.E.M.

\section{Results}

Specificity and validation of RT-PCR data

Initial experiments verified specific transcripts for all examined factors in bovine follicles (TI and GC) by RT-PCR (data for LH, FSH and ARO are not shown). Each PCR product showed 100\% homology to the known bovine genes after sequencing. To confirm the integrity of the mRNA templates and RT-PCR protocol, the housekeeping gene ubiquitin was examined in all samples. A representative example for the ubiquitin-specific RTPCR products $(189+417 \mathrm{bp})$ is shown in Fig. 2a. The relative signal intensities for PCR products specific for all examined factors were assessed after correction based on the ubiquitin PCR signal intensities.

\section{Characterisation of follicle classes}

For a better understanding and characterisation of the follicle classes determined by oestradiol- $17 \beta$ and progesterone concentrations in FF, the expression of mRNA for 


\section{(a) Ubiquitin}

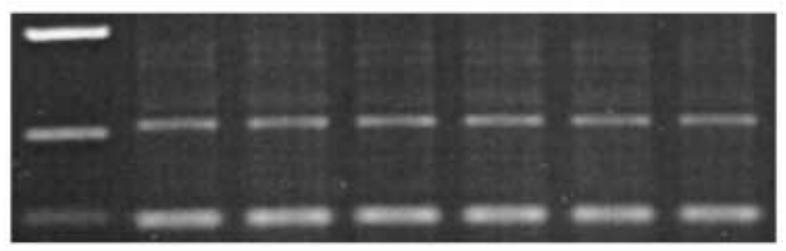

\section{(b) VEGF, VEGFR-1 and VEGFR-2}

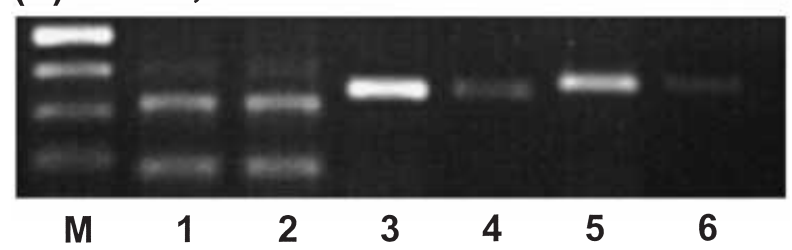

Figure 2 Specific RT-PCR products for (a) ubiquitin (189+417 bp) and (b) VEGF (186+318 bp), VEGFR-1 (351 bp), VEGFR-2 (379 bp) in preovulatory bovine follicles separated by agarose gel electrophoresis. (a) $M=$ DNA mass ladder $(200+400+800 \mathrm{bp})$. (b) $M=100$ bp DNA marker $(200+300+400+500$ bp $)$; lane 1 , VEGF in Tl; lane 2, VEGF in GC; lane 3, VEGFR-1 in TI; lane 4, VEGFR-1 in GC; lane 5, VEGFR-2 in Tl; lane 6, VEGFR-2 in GC.

FSHR, ARO and LHR were determined. The results of the densitometric analysis of mRNA expression (arbitrary units) by RT-PCR for FSHR, ARO, and LHR are shown in Fig. 1. As expected, FSHR mRNA increased with the oestradiol levels parallel to the elevation of ARO (Fig. 1a and b) only in GC. In contrast, LHR in TI tissue was already clearly expressed in oestradiol-17 $\beta$-negative follicles and expression did not change during further development (Fig. 1c). The LHR in GC is very weakly expressed during the first stages followed by a significant increase with oestradiol-17 $\beta>20 \mathrm{ng} / \mathrm{ml} \mathrm{FF}$ (Fig. 1d).

\section{Expression of $m R N A$ for VEGF and its receptors in follicle} classes

Analysis of the VEGF transcripts by RT-PCR shows that follicles (TI tissue and GC) express predominantly the 186 and $318 \mathrm{bp}$ bands, representing the two smallest VEGF isoforms $\left(\mathrm{VEGF}_{121}\right.$ and $\left.\mathrm{VEGF}_{165}\right)$ as shown in Fig. 2b. The expression of both transcripts in TI and GC appeared to be fairly stable during follicle growth. The results of the densitometric analysis of mRNA expression by RT-PCR for VEGF examined in GC and TI are shown in Fig. 3a and $\mathrm{d}$ respectively. VEGF mRNA expression in GC of small follicles was very weak with significant and continuous increases afterwards to maximum level in preovulatory follicles. In TI a clear signal could be detected already in small follicles (Fig. 3d) followed by a significant increase during further growth. The expression of mRNA for VEGFR-1 (Fig. 3b) and VEGFR-2 (Fig. 3c) was very weak in GC, without any regulating change during follicle growth. In contrast, TI showed a clear mRNA expression for both receptors in all follicle classes examined (Fig. 3e and f) without any regulatory change during follicle growth.

\section{VEGF protein concentration}

The VEGF protein levels in FF for the follicle classes are shown in Fig. 4a. The lowest VEGF levels in FF were measured in small follicle classes with a significant and continuous increase afterwards to maximum levels in preovulatory follicles. The VEGF follicle tissue concentration is shown in Fig. 4b. VEGF follicle tissue levels were significantly higher in large follicles.

\section{Expression of $m R N A$ for FGF2 and FGFR in follicle classes}

A representative example for RT-PCR specific products of FGF2 and FGFR in preovulatory follicles is given in Fig. 5b. The results of the densitometric analysis of mRNA expression by RT-PCR for FGF2 and FGFR examined in TI are presented in Fig. 6a and b. The expression intensity of FGF2 transcripts in TI significantly increased in follicles with oestradiol- $17 \beta>20-180 \mathrm{ng} / \mathrm{ml}$ FF (Fig. 6a). The expression signal for the FGFR in TI increased significantly with the beginning of oestradiol-17 $\beta$ production in FF (oestradiol-17 $\beta>0 \cdot 5-$ $5 \mathrm{ng} / \mathrm{ml} \mathrm{FF}$ ). In contrast, the expression of mRNA for FGF2 (Fig. 6c) and FGFR (Fig. 6d) in GC was very weak and without any regulatory change during follicle growth.

\section{Immunohistochemistry (FGF2 and VEGF)}

The histological evaluation revealed that those follicles characterised by a high oestradiol-17 $\beta$ content $(>180 \mathrm{ng} / \mathrm{ml})$ show a strong positive reaction for FGF2 (Fig. 7A and B) in the TI tissue. At the cellular level, FGF2 immunostaining was restricted to the cytoplasm of endothelial cells and pericytes (Fig. 7B) of the capillary bed located in the TI or larger vessels in the theca externa (Fig. 7A), while lymphatic vessels (arrow in Fig. 7A) were consistently negative. Follicles with low oestradiol-17 $\beta$ content (Fig. 7C) in FF or atretic follicles (Fig. 7D) showed no positive immunostaining of blood vessels in TI, whereas blood vessels localised in the stroma exhibited a positive FGF2 immunoreactivity.

An intense positive immunostaining for VEGF was observed in both GC and TI tissue (Fig. 7E) of mature follicles. Higher magnification (Fig. 7F) demonstrated specific immunolocalisation of VEGF in the cytoplasm of GC as well as in theca cells and in endothelial cells of blood vessels.

\section{Discussion}

In the present study we demonstrate that VEGF, FGF2 and their receptors are expressed clearly in bovine follicles 

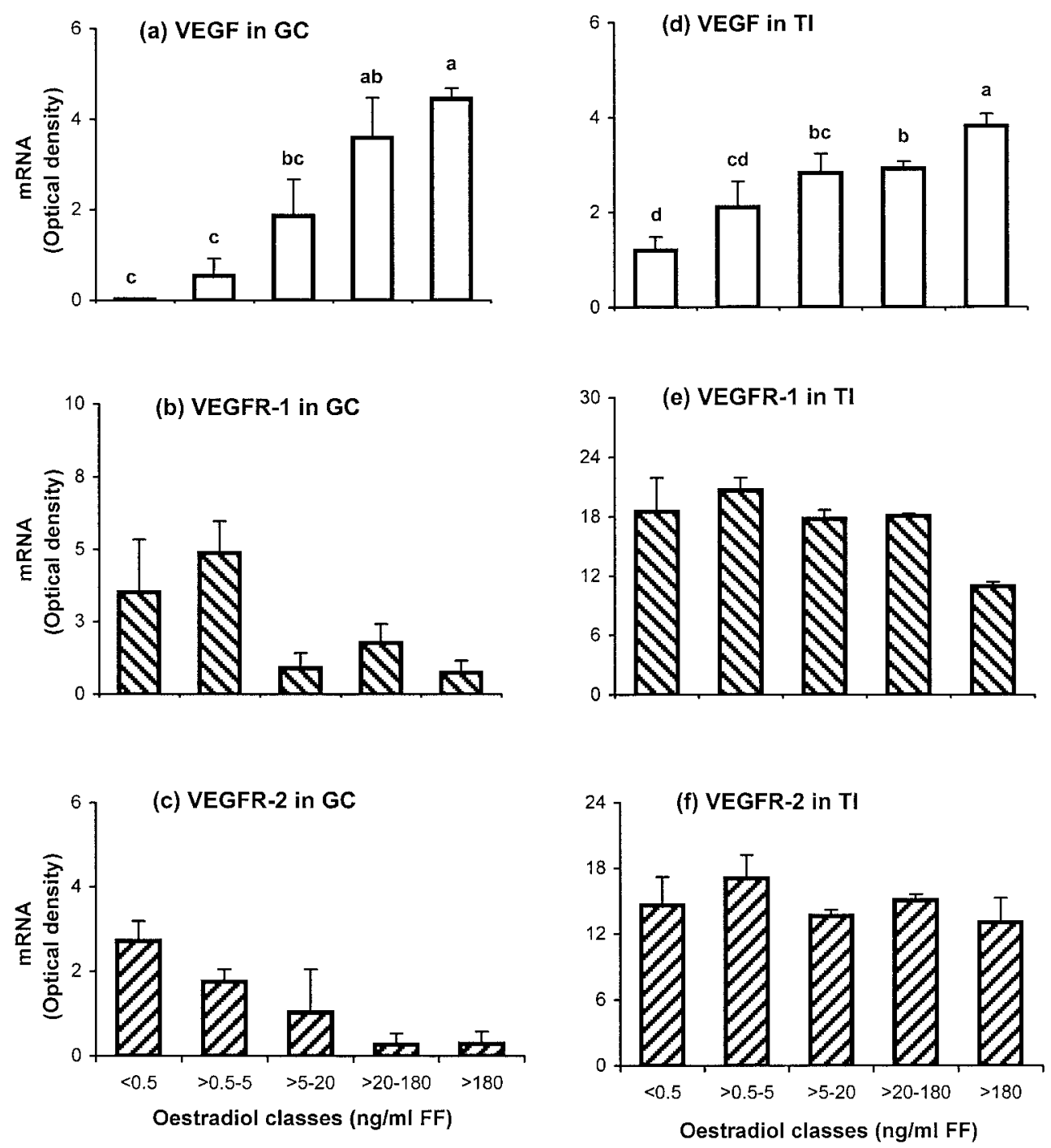

Figure 3 Densitometrically analysed RT-PCR results (arbitrary units) in different bovine follicle classes. (a) VEGF in GC (35 cycles); (b) VEGFR-1 in GC (30 cycles); (c) VEGFR-2 in GC (30 cycles); (d) VEGF in TI (35 cycles); (e) VEGFR-1 in TI (30 cycles); (f) VEGFR-2 in TI (30 cycles). Data are expressed as a means \pm S.E.M. ( $n=4$ or 5 follicles/class). Different superscripts denote statistically different values $(P<0 \cdot 05)$.

during final growth to preovulatory follicles. The expression of mRNA and localisation of protein show distinct differences between TI and GC layers.

The collection of our follicles from slaughterhouse material does not allow determination of the exact stage of follicular development. The expression of mRNA for FSHR, LHR and ARO supports our classification system of follicles according to the progesterone and oestradiol$17 \beta$ content in FF and allows some conclusions in comparison with data from the literature. Recently, expression of mRNAs for LHR, FSHR and ARO during growth, dominance, and atresia of bovine dominant follicles harvested during the first follicular wave of the oestrous cycle was reported (Xu et al. 1995a,b). The results suggested that expression of ARO was associated with recruitment (initiation of the wave) and mRNA expression for LHR was associated with selection of the dominant follicle. In another paper (Evans \& Fortune 1997) data suggest that selection occurred in the absence of detected levels of mRNA for LHR in GC. The level of expression of FSHR mRNA in GC did not vary significantly with follicular size. More recently (Bao et al. 1997), expression of mRNA for ARO was first detected in the GC of follicles 4-6 $\mathrm{mm}$ in diameter and almost all follicles 6-9 $\mathrm{mm}$ in diameter. Expression of LHR mRNA was first detected in the GC of one follicle $>8 \mathrm{~mm}$ per cow and was 

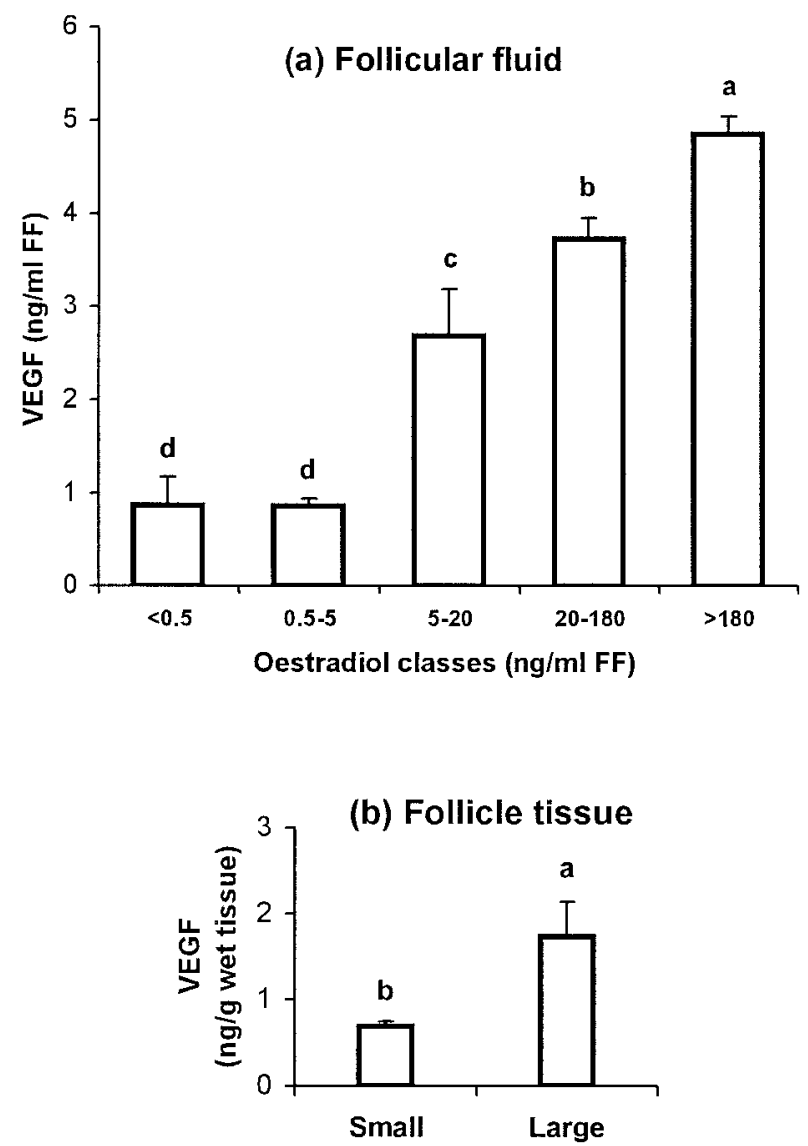

Figure 4 VEGF protein concentrations. (a) Bovine FF $(n=6-87$ follicles/class) and (b) bovine follicle tissue from small $(<9 \mathrm{~mm}$, $n=5$ pool) and large ( $>12 \mathrm{~mm}, n=5$ pool) follicles. Results are the means \pm S.E.M. Different superscripts denote statistically different values $(P<0 \cdot 05)$

limited to follicles that also expressed ARO mRNA in GC. From these data we assume that the following follicle classes may represent: oestradiol- $17 \beta<0.5 \mathrm{ng} / \mathrm{ml}$, FF follicles before recruitment; oestradiol- $17 \beta>0 \cdot 5-5 \mathrm{ng} / \mathrm{ml}$, FF just recruited; oestradiol- $17 \beta>20-180 \mathrm{ng} / \mathrm{ml}$, FF during or after the process of follicle selection; and oestradiol-17 $\beta>180 \mathrm{ng} / \mathrm{ml} \mathrm{FF}$, should be mature, preovulatory follicles. The results support our assumption that the follicles used were healthy.

We found only a weak FGF2 signal in GC. This agrees with earlier observations in the rat (Koos \& Olson 1989) that FGF2 is not expressed at significant levels by GC of rat preovulatory follicles, but that the mRNA is abundant in theca/interstitial tissue. Stirling et al. (1991) found no FGF2 mRNA in bovine GC in vivo. But FGF2 was produced by GC in cell culture (Neufeld et al. 1987). This could have been an effect of beginning luteinisation or due to the fact that GC produce FGF2 only in culture. As mentioned before, our FGFR primers detect FGFR-1 to

\section{(a) Ubiquitin}

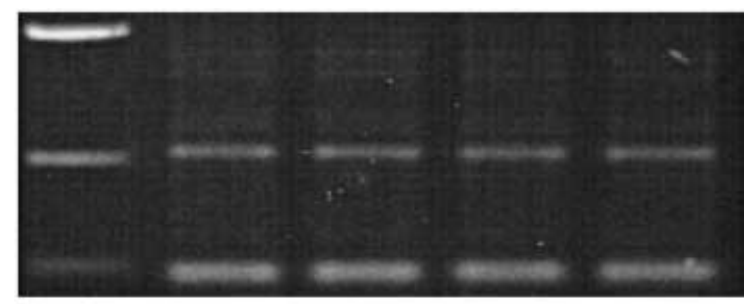

\section{(b) FGF2 and FGFR}

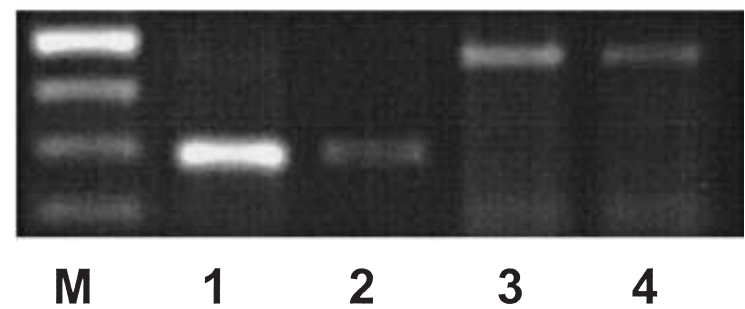

Figure 5 Specific RT-PCR products for (a) ubiquitin (189+417 bp) and (b) FGF2 (288 bp), FGFR (471 bp), in preovulatory bovine follicles separated by agarose gel electrophoresis. (a) $M=D N A$ mass ladder $(200+400+800$ bp). (b) $M=100$ bp DNA marker $(200+300+400+500$ bp); lane 1, FGF2 in Tl; lane 2, FGF2 in GC; lane 3, FGFR in Tl; lane 4, FGFR in GC.

-4 (Xin et al. 1994). It is not clear which subtype of alternatively spliced isoforms are targeted by our primer. After applying a gel-retardation technique, two different types of FGFR were found in the bovine ovary using a simple electrophoretic separation of specific PCR products. Type FGFR-1 was found in GC and cumulus cells, but a mixture of FGFR-1 and -2 in thecal tissue (Einspanier et al. 1999a). FGF-2 interacts with highaffinity tyrosine kinase FGFRs and low-affinity heparan sulphate proteoglycans in target cells. Both interactions are required for FGF-2-mediated biological responses (Liekens et al. 1999, Rege et al. 1999). Alternative splicing in the extracellular region of FGFR-1 to -3 generates receptor variants (IIIb and IIIc isoforms) with different ligand-binding affinities (Beer et al. 2000). In our study the FGFR mRNA is, similar to the FGF2 mRNA, only weakly expressed in GC compared with TI and increasing oestradiol-17 $\beta$ levels show no regulatory effect, indicating that FGF2 and the receptor in GC are not involved in follicular growth regulation. In contrast, FGF2 mRNA expression in TI increased with rising oestradiol in the FF. The FGF2 protein could be localised in the blood capillaries of TI by immunohistochemistry. The selective demonstration of FGF2 in vascular cells of mature follicles suggests that FGF2 could play an important role during follicle selection and dominance in the cow. The early mRNA expression of the FGFR before the ligand in TI may support this assumption. 

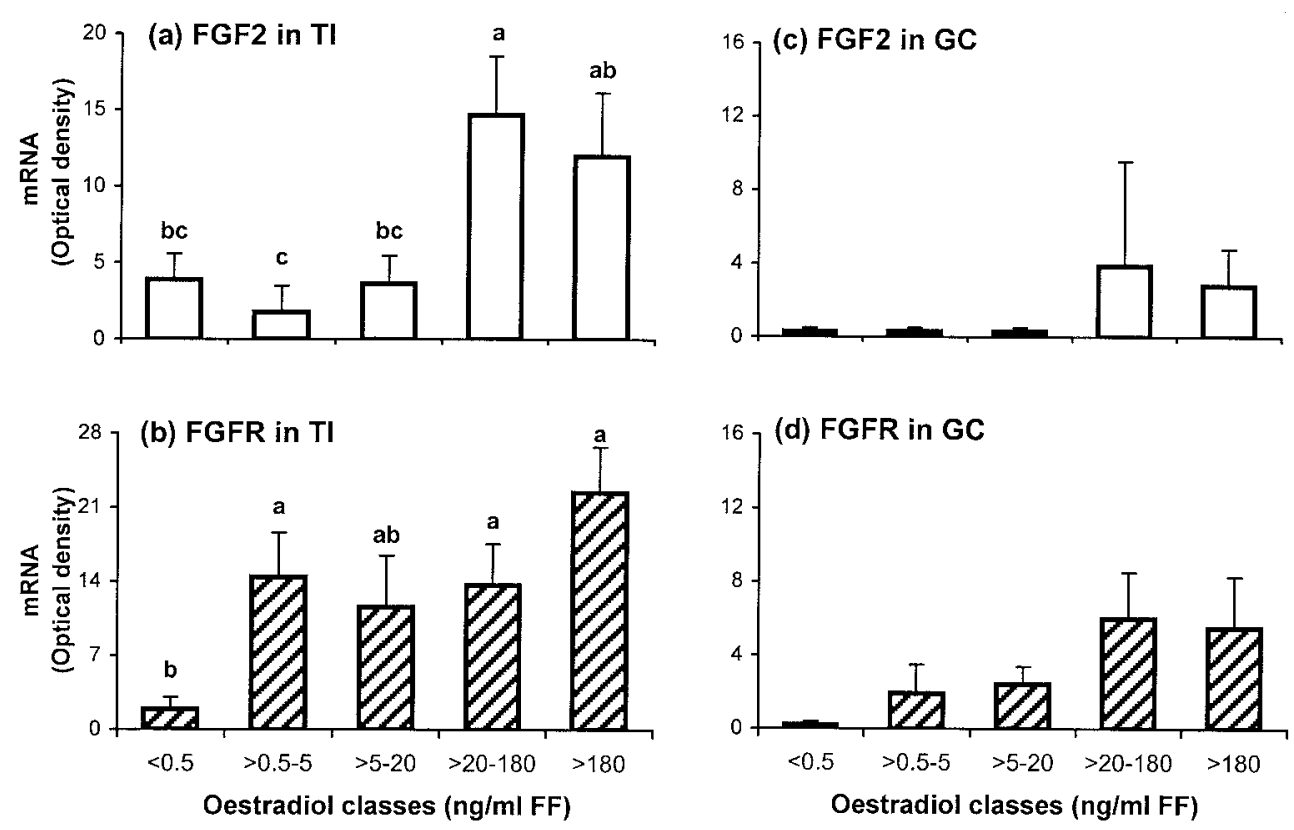

Figure 6 Densitometrically analysed RT-PCR results (arbitrary units) in different bovine follicle classes. (a) FGF2 in TI (30 cycles); (b) FGFR in TI (30 cycles); (c) FGF2 in GC (30 cycles); (d) FGFR in GC (30 cycles). Data are expressed as a means \pm S.E.M. $(n=4-9$ follicles/class). Different superscripts denote statistically different values $(P<0 \cdot 05)$.

In contrast to FGF2, VEGF mRNA is clearly expressed in GC and TI, with a significant up-regulation during maturation of follicles. However, the expression of VEGF in the rat ovary, detected by in situ hybridisation, showed little or no VEGF mRNA in GC, with the exception of cumulus cells (Phillips et al. 1990). Another study in the rat ovary demonstrated that VEGF is expressed by both GC and theca cells and could be stimulated by human chorionic gonadotrophin (Koos 1995). The VEGF mRNA expression in our study is confirmed by the localisation of the protein, increased FF concentration and increased concentration in total follicle tissue of assumed preovulatory follicles. The VEGF in GC may not affect GC themselves since mRNA for both receptors is only weakly expressed in GC during the mature stage of follicles. In contrast, as shown by Einspanier et al. (1999b), cumulusoocyte complexes (COC) showed enriched transcriptional activity for VEGF receptor mRNA especially during in vitro maturation (IVM) after FSH stimulation, suggesting COC as a potent target for VEGF secreted from GC into FF. Addition of exogenous VEGF during early IVM induced a significant increase in the number of blastomeres per embryo (Einspanier et al. 1999b). The target for VEGF expressed in GC and TI could be the TI endothelial cells where both receptors (VEGFR-1 and VEGFR-2) are found (De Vries et al. 1992, Terman et al. 1992).

Our immunohistochemical localisation of VEGF in the GC and theca cells agrees with recent observations in the human ovary (Gordon et al. 1996, Yamamoto et al. 1997).
The VEGF immunostaining in the GC was weak or absent in small follicles but increased clearly in large mature follicles.

The strong expression of mRNA for the angiogenic factors VEGF and FGF2 in the mature follicles raises the exciting possibility that these factors may play a role in the angiogenesis that accompanies follicular growth and selection. Previous work in primate follicles has shown that the density of the microvascular network of the selected follicle is at least double that of follicles of lesser maturity. This increased capillary density resulted in a greater delivery of gonadotrophic hormone to the selected follicle in vivo (Zeleznik et al. 1981). The process of follicle selection requires a mechanism by which a single follicle continues to survive in the presence of gonadotrophin concentrations which are insufficient to support the growth of other follicles (Zeleznik \& Kubik 1986). Both VEGF and FGF2 are known as very potent factors for angiogenesis (Gospodarowicz \& Thakral 1978, Ferrara \& Davis-Smyth 1997). Growth factor activation enables quiescent, resting endothelial cells to proteolytically degrade their underlying extracellular matrix, to invade and directionally migrate towards the angiogenic stimulus, and to proliferate and organise into new three-dimensional capillaries (Augustin 1998). Our finding that VEGF is localised in theca cells underlines these assumptions, suggesting that VEGF may act as a chemoattractant for sprouting endothelial cells. This is supported by the dominant expression of the secretory forms of $\mathrm{VEGF}_{121}$ 

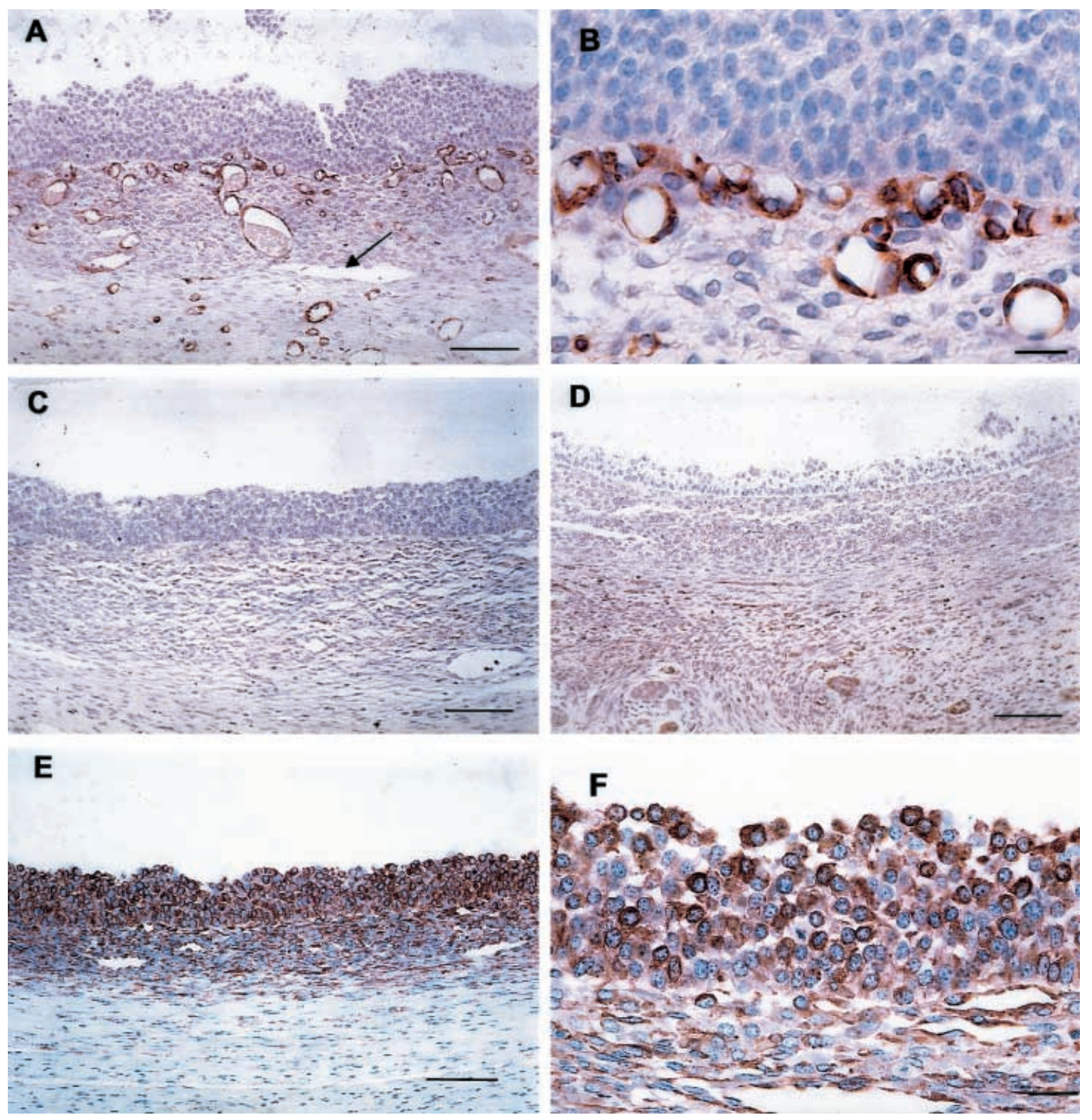

Figure 7 Immunohistochemical localisation of FGF2 and VEGF in bovine follicles. Positive staining for FGF2 was observed in oestrogen-dominant follicles (A, B) but not in progesterone dominant follicles (C) and atretic follicles (D). Arrow in panel A indicates negatively stained lymphatic vessels. Strong positive immunostaining for VEGF is observed in granulosa and theca cells of mature follicles (E, F). Bar: $100 \mu \mathrm{m}(\mathrm{A}, \mathrm{C}-\mathrm{E}) ; 20 \mu \mathrm{m}(\mathrm{B}, \mathrm{F})$.

and VEGF $_{165}$ whose receptors (VEGFR-1 and VEGFR-2) are found exclusively on endothelial cells. Therefore VEGF localised in and secreted from theca cells may act paracrinely as a chemoattractant to sprouting endothelial cells. FGF2 is a heparin-binding growth factor which occurs in several isoforms resulting from alternative initiations of translation: an $18 \mathrm{kDa}$ cytoplasmic isoform and four larger molecular weight nuclear isoforms (22, $22 \cdot 5,24$ and $34 \mathrm{kDa}$ ). Although devoid of a signal peptide, it could be secreted. This protein acts mainly through a paracrine/autocrine mechanism involving high affinity receptors, but also through still unknown intracrine processes on intracellular targets (Okada-Ban et al. 2000). In the early bovine corpus luteum FGF2 is observed exclusively in vascular cells and represents the $18 \mathrm{kDa}$ form (Schams et al. 1994), which was previously shown to be secreted (Escaffit et al. 2000). The localisation of FGF2 predominantly in capillaries of TI suggests an autocrine 
function on endothelial cells. Two in vitro studies (Pepper et al. 1992, Goto et al. 1993) have demonstrated that combined administration of VEGF and FGF2 to endothelial cell cultures in three-dimensional collagen gels results in much greater and more rapid capillary tubule formation than the additive effects of either mitogen alone. This synergism was confirmed recently under in vivo conditions where combined administration of VEGF and FGF2 stimulated significantly greater and more rapid augmentation of collateral circulation, resulting in superior haemodynamic improvement compared with either VEGF or FGF2 alone (Asahara et al. 1995). VEGF has also been known to have a vascular permeability enhancing activity 50000 times that of histamine on a molecular basis (Dvorak et al. 1995), which could be responsible for the leakiness of the vascular bed in mature follicles which may play a paramount role in the delivery of gonadotrophins and of low density lipoprotein cholesterol for progesterone and androgen biosynthesis, resulting in an increased supply of substrate to GC for the production of oestradiol-17 $\beta$. But VEGF may also have a survival function for endothelial cells of capillaries surrounding theca cells. As shown by Alan et al. (1995), a certain threshold concentration of VEGF is required to inhibit apoptosis of the endothelial cells and is essential for the stabilisation of the newly formed blood vessels.

In conclusion, our results demonstrate the localisation and distinct up-regulation during development of bovine follicles of mRNA and of protein concentrations of VEGF and FGF2, factors known to be most important for angiogenesis. The results are consistent with the hypothesis that these angiogenic factors may be involved in the proliferation of capillaries that accompanies the selection of the preovulatory follicle, resulting in an increased supply of nutrients and precursors, and therefore supporting growth of the dominant follicle.

\section{Acknowledgements}

The authors thank Dr Gospodarowicz, Chiron Corp., Berkeley, CA, USA for the supply of bovine FGF2 and VEGF for immunisation and Mrs Gabi Schwentker for technical help. We greatly acknowledge the support of the work by the German Research Foundation (DFG, Scha 257/II-3 and Scha 257/14-1).

\section{References}

Alan T, Hemo I, Itin A, Peer J, Stone J \& Keshet E 1995 Vascular endothelial growth factor acts as a survival factor for newly formed retinal vessels and has implications for retinopathy of prematurity. Nature Medicine 1 1024-1028.

Asahara T, Bauters C, Zheng LP, Takeshita S, Bunting S, Ferrara N, Symes JF \& Isner JM 1995 Synergistic effect of vascular endothelial growth factor and basic fibroblast growth factor on angiogenesis in vivo. Circulation 92 II365-II371.
Asakai R, Song SY, Itoh N, Yamakuni T, Tamura K \& Okamoto R 1994 Differential gene expression of fibroblast growth factor receptor isoforms in rat ovary. Molecular Cell Endocrinology 104 $75-80$.

Augustin HG 1998 Antiangiogenic tumour therapy: will it work? Trends in Pharmacological Sciences 19 216-222.

Bao B, Garverick HA, Smith GW, Smith MF, Salfen BE \& Youngquist RS 1997 Changes in messenger ribonucleic acid encoding luteinizing hormone receptor, cytochrome P450-side chain cleavage, and aromatase are associated with recruitment and selection of bovine ovarian follicles. Biology of Reproduction $\mathbf{5 6}$ $1158-1168$.

Beer HD, Vindevoghel L, Gait MJ, Revest JM, Duan DR, Mason I \& Dickson C 2000 Werner S. Fibroblast growth factor (FGF) receptor 1-IIIb is a naturally occurring functional receptor for FGFs that is preferentially expressed in the skin and the brain. Journal of Biological Chemistry 26 16091-16097.

Chomczynski P \& Sacchi N 1987 Single-step method of RNA isolation by acid guanidinium thiocyanate-phenol-chloroform extraction. Analytical Biochemistry 162 156-159.

Connolly DT 1991 Vascular permeability factor: a unique regulator of blood vessel function. Journal of Cellular Biochemistry 47 219-223.

De Vries C, Escobedo JA, Ueno H, Houck KA, Ferrara N \& Williams LT 1992 The fms-like tyrosine kinase, a receptor for vascular endothelial growth factor. Science 255 989-991.

Dvorak HF, Brown LF, Detmar M \& Dvorak AM 1995 Vascular permeability factor/vascular endothelial growth factor, microvascular hyperpermeability, and angiogenesis. American Journal of Pathology 146 1029-1039.

Einspanier R, Gabler C, Bieser B, Einspanier A, Berisha B, Kosmann M, Wollenhaupt K \& Schams D 1999a Growth factors and extracellular matrix proteins in interactions of cumulus-oocyte complex, spermatozoa and oviduct. Journal of Reproduction and Fertility 54 359-365.

Einspanier R, Müller K, Bieser B, Kosmann M \& Schams D 19996 Differential expression of vascular endothelial growth factor (VEGF) in bovine ovarian follicles and first effects of VEGF applied during in vitro maturation of oocytes. Journal of Reproduction and Fertility 237.

Escaffit F, Estival A, Bertrand C, Vaysse N, Hollande E \& Clemente F 2000 FGF-2 isoforms of 18 and $22.5 \mathrm{kDa}$ differentially modulate t-PA and PAI-1 expressions on the pancreatic carcinoma cells AR 4-2J: consequences on cell spreading and invasion. International Journal of Cancer 15 555-562.

Evans ACO \& Fortune JE 1997 Selection of the dominant follicle in cattle occurs in the absence of differences in the expression of messenger ribonucleic acid for gonadotropin receptors. Endocrinology 138 2963-2971.

Ferrara N \& Davis-Smyth T 1997 The biology of vascular endothelial growth factor. Endocrine Reviews 18 4-25.

Ferrara N, Hauk K, Jakeman L \& Leung DW 1992 Molecular and biological properties of the vascular endothelial growth factor family of proteins. Endocrine Reviews 13 18-32.

Fortune JE 1994 Ovarian follicular growth and development in mammals. Biology of Reproduction 50 225-232.

Gabler C, Lauer B, Einspanier A, Schams D \& Einspanier R 1997 Detection of mRNA and immunoreactive proteins for acidic and basic fibroblast growth factor and expression of the fibroblast growth factor receptors in the bovine oviduct. Journal of Reproduction and Fertility 109 213-221.

Gabler C, Einspanier A, Schams D \& Einspanier R 1999 Expression of vascular endothelial growth factor (VEGF) and its corresponding receptors (flt-1 and flk-1) in the bovine oviduct. Molecular Reproduction and Development 53 376-383.

Garrido C, Saule S \& Gospodarowicz D 1993 Transcriptional regulation of vascular endothelial growth factor gene expression in ovarian bovine granulosa cells. Growth Factors 8 109-117. 
Gordon JD, Mesiano S, Zaloudek CJ \& Jaffe RB 1996 Vascular endothelial growth factor localization in human ovary and fallopian tubes: possible role in reproductive function and ovarian cyst formation. Journal of Clinical Endocrinology and Metabolism $\mathbf{8 1}$ 353-359.

Gospodarowicz D \& Thakral KK 1978 Production of a corpus luteum angiogenic factor responsible for proliferation of capillaries and neo-vascularization of the corpus luteum. PNAS 75 847-851.

Gospodarowicz D, Massoglia S, Cheng J \& Fujii DK 1986 Effects of fibroblast growth factor and lipoproteins on the proliferation of endothelial cells derived from bovine adrenal cortex, brain cortex, and corpus luteum capillaries. Journal of Cellular Physiology 127 121-136.

Gospodarowicz D, Ferrara N, Schweigerer L \& Neufeld G 1987 Structural characterization and biological functions of fibroblast growth factor. Endocrine Reviews 8 95-114.

Goto F, Goto K, Weindel K \& Folkman J 1993 Synergistic effects of vascular endothelial growth factor and basic fibroblast growth factor on the proliferation and cord formation of bovine capillary endothelial cells within collagen gels. Laboratory Investigation 69 508-517.

Grazul-Bilska AT, Redmer DA, Killilea SD, Zheng J \& Reynolds LP 1993 Initial characterization of endothelial mitogens produced by bovine corpora lutea from the estrous cycle. Biochemistry and Cell Biology 71 270-277.

Hsu SM, Raine L \& Fanger H 1981 Use of avidin-biotin peroxidase complex $(\mathrm{ABC})$ in immunoperoxidase technique: a comparison between $\mathrm{ABC}$ and unlabelled antibody (PAP procedure). Journal of Histochemistry and Cytochemistry 29 577-580.

Klagsbrun M \& D'Amore PA 1991 Regulators of angiogenesis. Annual Review of Physiology $\mathbf{5 3}$ 217-239.

Koos RD 1995 Increased expression of vascular endothelial growth/permeability factor in the rat ovary following an ovulatory gonadotropin stimulus: potential roles in follicle rupture. Biology of Reproduction 52 1426-1435.

Koos RD \& Olson CE 1989 Expression of basic fibroblast growth factor in the rat ovary: detection of mRNA using reverse transcription-polymerase chain reaction amplification. Molecular Endocrinology 3 2041-2048.

Liekens S, Leali D, Neyts J, Esnouf R, Rusnati M, Dell'Era P, Maudgal PC, De Clercq E \& Presta M 1999 Related modulation of fibroblast growth factor-2 receptor binding, signaling, and mitogenic activity by heparin-mimicking polysulfonated compounds. Molecular Pharmacology 56 204-213.

Meyer HHD, Sauerwein H \& Mutayoba BM 1990 Immunoaffinity chromatography and a biotin-streptavidin amplified enzyme immunoassay for sensitive and specific estimation of estradiol-17 $\beta$. Journal of Steroid Biochemistry 35 263-269.

Neufeld G, Ferrara N, Schweigerer L, Mitchell R \& Gospodarowicz D 1987 Bovine granulosa cells produce basic fibroblast growth factor. Endocrinology 121 597-603.

Okada-Ban M, Thiery JP \& Jouanneau J 2000 Fibroblast growth factor-2. International Journal of Biochemistry and Cell Biology 32 263-267.

Pepper MS, Ferrara N, Orci L \& Montesano R 1992 Potent synergism between vascular endothelial growth factor and basic fibroblast growth factor in the induction of angiogenesis in vitro. Biochemical and Biophysical Research Communications 189 824-831.

Phillips HS, Hains J, Leung DW \& Ferrara N 1990 Vascular endothelial growth factor is expressed in rat corpus luteum. Endocrinology 127 965-967.

Prakash BS, Meyer HHD, Schallenberger E \& Van de Wiel DFM 1987 Development of a sensitive enzyme immunoassay (EIA) for progesterone determination in unextracted bovine plasma using the second antibody technique. Journal of Steroid Biochemistry 28 623-627.

Rege AA, Bjercke RJ, Erichsen D, Owens R, Stephan CC \& Brock TA 1999 Development of novel monoclonal antibodies for the analysis of functional sites in FGF-2. Growth Factors 16 161-169.
Richards RG \& Almond GW 1994 Identification and distribution of tumor necrosis factor $\alpha$ receptors in pig corpora lutea. Biology of Reproduction 51 1285-1291.

Savio D, Keenan L, Boland MP \& Roche JF 1988 Pattern of growth of dominant follicles during the oestrous cycle of heifers. Journal of Reproduction and Fertility 83 663-671.

Schams D, Amselgruber W, Einspanier R, Sinowatz F \& Gospodarowicz D 1994 Localization and tissue concentration of basic fibroblast growth factor in the bovine corpus luteum. Endocrine 2 907-912.

Senger DR, Van de Water L, Brown LF, Nagy JA, Yeo KT, Yeo TK, Berse B, Jackman RW, Dvorak AM \& Dvorak HF 1993 Vascular permeability factor (VPF, VEGF) in tumor biology. Cancer and Metastasis Reviews 12 303-324.

Sirois J \& Fortune JE 1988 Ovarian follicular dynamics during the estrous cycle in heifers monitored by real-time ultrasonography. Biology of Reproduction 39 308-317.

Stauber DJ, DiGabriele AD \& Hendrickson WA 2000 Structural interactions of fibroblast growth factor receptor with its ligands. PNAS 97 49-54.

Stirling D, Waterman MR \& Simpson ER 1991 Expression of mRNA encoding basic fibroblast growth factor (bFGF) in bovine corpora lutea and cultured luteal cells. Journal of Reproduction and Fertility 91 1-8.

Terman BI, Vermazen MD, Carrion ME, Dimitrov D, Armellino DC, Gospodarowicz D \& Bohlen P 1992 Identification of the KDR tyrosine kinase as a receptor for vascular endothelial growth factor. Biochemical and Biophysical Research Communications 34 1578-1586.

Tischer E, Gospodarowicz D, Mitchell R, Silva M, Schilling J, Lau K, Crisp T, Fiddes JC \& Abraham JA 1989 Vascular endothelial growth factor: a new member of the platelet-derived growth factor gene family. Biochemical and Biophysical Research Communications 165 $1198-1206$.

Xin X, Johnson AD, Scott-Burden T, Engler D \& Casscells W 1994 The predominant form of fibroblast growth factor receptor expressed by proliferating human arterial smooth muscle cells in culture is type I. Biochemical and Biophysical Research Communications 204 557-564

Xu Z, Garverick HA, Smith GW, Smith MF, Hamilton SA \& Youngquist RS 1995a Expression of follicle-stimulating hormone and luteinizing hormone receptor messenger ribonucleic acids in bovine follicles during the first follicular wave. Biology of Reproduction 53 951-957.

Xu Z, Garverick HA, Smith GW, Smith MF, Hamilton SA \& Youngquist RS $1995 b$ Expression of messenger ribonucleic acid encoding cytochrome P450 side-chain cleavage, cytochrome P450 17 alpha-hydroxylase, and cytochrome P450 aromatase in bovine follicles during the first follicular wave. Endocrinology 136 981-989.

Yamamoto S, Konishi I, Tsuruta Y, Nanbu K, Mandai M, Kuroda H, Matsushita K, Hamid AA, Yura Y \& Mori T 1997 Expression of vascular endothelial growth factor (VEGF) during folliculogenesis and corpus luteum formation in the human ovary. Gynecology and Endocrinology 11 371-381.

Zeleznik AJ \& Kubik CJ 1986 Ovarian responses in macaques to pulsatile infusion of follicle-stimulating hormone (FSH) and luteinizing hormone: increased sensitivity of the maturing follicle to FSH. Endocrinology 119 2025-2032.

Zeleznik AJ, Schuler HM \& Reichert LE Jr 1981 Gonadotropin-binding sites in the rhesus monkey ovary: role of the vasculature in the selective distribution of human chorionic gonadotropin to the preovulatory follicle. Endocrinology 109 356-362.

Received 14 January 2000

Revised manuscript received 5 May 2000

Accepted 8 August 2000 